\title{
The Proportionality of Unilateral "Targeted" Sanctions: Whose Interests Should Count?
}

\author{
Alexandra Hofer \\ Assistant Professor, Universiteit Utrecht, School of Law, Department of \\ International and European Law, Utrecht, The Netherlands \\ a.s.hofer@uu.nl
}

\begin{abstract}
Comprehensive sanctions were considered to be disproportionate in their collateral effects for the harm caused to the populations of sanctioned States. With the emergence of the concept of targeted sanctions, questions regarding proportionality were expected to fade away. After all, targeted sanctions were supposed to be inherently proportional precisely because they were targeted. Nevertheless, the use of selective embargoes, also known as sectoral sanctions, continues to give rise to issues of proportionality. One of the lacunas of the current system is there is no uniform proportionality standard that applies to unilateral sanctions as these measures fall with different types of legal regimes, each with their own proportionality standard. Drawing from recent State practice and the existing legal standards, the present contribution maps the respective interests that should inform proportionality discussions in distinct sanctions regimes and explores to what extent the proportionality principle can account for each of these interests.
\end{abstract}

\section{Keywords}

proportionality - unilateral sanctions - sectoral sanctions - retorsions countermeasures

\section{1 \\ Introduction}

The concept "sanction" is widespread in international politics and international law; in spite of its frequent use, however, its definition remains highly 
imprecise. In the most general sense, sanctions are coercive foreign policy tools; "coercive" refers to the pressure imposed through these measures, which is usually in the form of economical, financial, personal or political costs. This pressure has been explained as "hardship" and "pain", even as "strategically applied force". Sanctions fall within different legal categories under international law, mainly acts of retorsion, internationally wrongful acts and (collective) countermeasures. Consequently the rules, if any, governing their adoption vary. The reason they are adopted equally varies, as sanctions pursue different political objectives (such as coercing the target into changing its behaviour, preventing a target from behaving in a certain manner, stigmatising or outcasting the target, etc.). According to the present author, within the international legal order, sanctions are primarily a form of inter-State punishment; they are an imposition of costs in response to a (perceived) breach of international law. ${ }^{2}$ They signal the sanctioner's commitment to the violated norm and its disapproval of the sanctioned's behaviour, but also frequently aim to pressure the target into changing its behaviour and complying with international law.

Who imposes the cost and against whom also differ. This contribution focuses on unilateral sanctions, ${ }^{3}$ which are measures adopted by a State on the basis of its national legislation against a State or a non-State actor. They can equally be implemented by an international organisation pursuant to its constitutive act against a non-member State or non-State actor. At present, the European Union (EU) is the most active international organisation in this respect. The present discussion is limited to unilateral sanctions adopted against State actors, and targeted sectoral sanctions in particular, which are measures that are not targeted against individuals but that impose restrictions upon a State's economic, financial or energy sector.

It has been recognised that sanctions can have severe consequences not only on the target but also on third parties that are not directly targeted but still affected, notably on the civilian population of the targeted State and third countries, including economic operators under their jurisdiction. To tackle

1 R. Nephew, The Art of Sanctions: A View from the Field (Columbia University Press, New York, 2018) pp. 9 and 128. In his view, at p. 9 , "sanctions are generally intended to create hardship - or to be blunt, 'pain' - that is sufficiently onerous that the sanctions target changes its behaviour". See generally chap. 4. See also: M. O'Connell, 'Debating the Law of Sanctions', 13:1 European Journal of International Law (2012) p. 74: "Analysing sanctions as weapons is reasonable".

2 Touched upon in A. Hofer, 'The Efficacy of Targeted Sanctions in Enforcing Compliance with International Law', 113 AJIL Unbound: Symposium on Unilateral Targeted Sanctions (2019) pp. 163-168. See also: A. Hofer, 'Creating and Contesting Hierarchy: the Punitive Effect of Sanctions in a Horizontal System', No. 125 Afers Internacionals (2020), pp. 15-37.

3 Multilateral sanctions, such as those adopted by the United Nations Security Council against UN member States, are therefore excluded from the present discussion. 
this issue, various authors have argued in favour of applying, inter alia, the proportionality principle to these measures. ${ }^{4}$ The difficulty lies in the fact that there is no general rule that establishes what a proportionate sanction is. With the exception of sanctions that fall within the countermeasure framework, unilateral sanctions are grossly unregulated under international law; and even within the countermeasure framework the principle's definition is subject to criticism. ${ }^{5}$

The present contribution addresses the question of proportionate sanctions by focusing on the interests of the actors that adopt the measures but also those that are affected. It first demonstrates the need for proportionate sanctioning and illustrates how sanctions affect different actors (section 2). It illustrates that those affected, and hence the interests that count, can extend beyond the sanctioning and sanctioned States and include third parties that are not targeted but still affected, notably the civilian population of the targeted country and third-countries. It is then explained that, in its current variable and limited application to unilateral sanctions, the proportionality principle is unable to satisfactorily balance the interests of all actors involved (section 3). The article concludes by arguing that the proportionality assessment should apply to unilateral sanctions regardless of their legal nature. It should take into account the interests of the sender, the target, affected third parties as well as the international community. In weighing these interests against one and other, the appropriateness and necessity of sanctions should be included in the proportionality test (section 4).

\section{The Quest for Proportionate Sanctions}

\subsection{From Comprehensive to Targeted Sanctions}

The proportionality principle is a general principle of international law; it is found throughout different fields of international law - notably the law of the sea, the use of force, international humanitarian law, human rights law,

4 W.M. Reisman and D.L. Stevick, "The Applicability of International Law Standards to United Nations Economic Sanctions Programmes', 9 European Journal of International Law (1998) pp. 86-141; C. Michaelsen, 'Human Rights as Limits for the Security Council: A Matter of Substantive Law or Defining the Application of Proportionality?', 19:3 Journal of Conflict and Security Law (2014) pp. 451-469; D. Joyner, 'United Nations Counter-Proliferation Sanctions and International Law', in L. van den Herik (ed.), Research Handbook on UN Sanctions and International Law (Edward Elgar Publishing, Abingdon, 2017) p. 105.

5 Discussed in infra section 3.2. 
international trade law - as well as in regional and domestic law. ${ }^{6}$ As made clear throughout this special issue, the principle's definition and application vary according to the areas in which it is applied. In its most basic sense, it is a balancing act of the different rights and interests at stake. ${ }^{7}$ Given their close relation to interests, it would be reasonable for the proportionality principle, as a balancing act, to apply to unilateral sanctions. Under the International Emergency Economic Powers Act, the president of the United States can only implement sanctions in response to a "national emergency", a concept that generally enjoys a broad interpretation by the US presidency. A national emergency has been declared to justify sanctions adopted in response to situations of political unrest in Burundi, Nicaragua, Venezuela, to name but a few. ${ }^{8}$ Executive orders imposing sanctions frequently invoke human rights violations or the transgression of democratic principles, which the target would be responsible for. A further illustration is found under Article 21(2) Treaty on European Union (TEU), the EU is permitted to adopt restrictive measures in order to, inter alia: "safeguard its values, fundamental interests, security, independence and integrity" and "consolidate and support democracy, the rule of law, human rights and the principles of international law". In this context, interests are not only related to a country's national security, but also the values it wishes to uphold in its international relations. In spite of this core link with interests, there is no uniform, predetermined standard for how the proportionality principle should apply to sanctions, or indeed whose interests count. If anything, given the public interests invoked by the sender, the scale usually tips in favour of the sender, without considering the target's interests.

In addition to balancing conflicting interests, the general definition of proportionality includes the criteria of suitability and necessity. ${ }^{9}$ The question is

6 J. Gardam, 'Proportionality in International Law', Oxford Bibliographies, <https://www. oxfordbibliographies.com/view/document/obo-978o199796953/obo-978o199796953-0147. xml\#obo-978o199796953-0147-bibItem-ooo2>; E. Crawford, 'Proportionality', in R. Wolfrum (ed.), Max Planck Encyclopedia of Public International Law vol. viII (Oxford University Press, Oxford, 2012) p. 533 .

7 Crawford, supra note 6, paras. 23-24. See, i.e., E. Cannizzaro, 'Proportionality and Margin of Appreciation in the Whaling Case: Reconciling Antithetical Doctrines?', 27:4 European Journal of International Law (2017) p. 1068: the proportionality principle "determine[s] the legality of unilateral measures taken by a state to protect certain interests protected by international law on the basis of the detrimental effect produced on other interests that are entitled to legal protection".

8 D. Lu, 'Trump's Emergency Declaration Is the First since $9 / 11$ to Authorize Military Action', The New York Times, 15 February 2019, https://www.nytimes.com/interactive/2019/o2/15/us/list-ofnational-emergencies.html.

9 Crawford, supra note 6, para. 2. 
whether the measure imposed - which in the case of sanctions entails a limitation on the rights or interests of another party - is not only appropriate but also whether there is not a less intrusive measure. Necessity can also include an assessment of whether the sanction will achieve its objective, and hence if it will be effective. However, this standard is not currently applied to sanctions. ${ }^{10}$ In general, the necessity of these coercive measures is limited to determining whether there is causal link between the sanction and the context of its adoption, the matter of their effectiveness plays no role.

In the context of sanctions, one could also question whether the goal pursued by the sanctioner is appropriate. After all, they are policy tools that can serve a broad spectrum of aims. This amounts to a "functional approach" to proportionality.11 As such, the proportionality of a sanction would vary according to the goal pursued by the sender. Cannizzaro, for instance, proposed such an approach to the proportionality of countermeasures, which he coined "external proportionality". ${ }^{12}$ Depending on what he qualifies as their normative, retributive, coercive and executive functions, the proportionality of countermeasures would be assessed differently. To the extent that sanctions constitute a form of punishment, their appropriateness within the international legal order is questionable; the vertical nature of these policy tools contradicts the horizontal structure of international law. Evidently, the "punitive effects" of sanctions ${ }^{13}$ cannot be solved by the proportionality principle but this does not mean that there should not be regulations governing these measures' adoption.

In spite of the fact that the proportionality principle is not applied uniformly to sanctions, it is implicit in the transition from comprehensive to targeted sanctions. ${ }^{14}$ This shift occurred following the negative humanitarian consequences provoked by the United Nations Security Council (UNSC) sanctions regimes against Yugoslavia, Haiti ${ }^{15}$ and, infamously, Iraq. ${ }^{16}$ Whereas comprehensive sanctions made no distinction between the decision-makers whose policy the sanctioners wanted to influence and the general population of that

$10 \quad$ O'Connell, supra note 1, p. 78.

11 E. Cannizzaro, 'The Role of Proportionality in the Law of International Countermeasures', 12:5 European Journal of International Law (2001) pp. 897-898.

12 Cannizzaro, supra note 11, p. 899.

13 Hofer, supra note 2, p. 167.

14 Timeline provided here: U. Friedman, 'Smart Sanctions: a Short History', Foreign Policy, 23 April 2012, https://foreignpolicy.com/2012/04/23/smart-sanctions-a-short-history/.

15 The UN sanctions against Yugloslavia and Haiti are discussed in: Reisman and Stevick, supra note 4, pp. 112-24.

16 J. Müller and K. Müller, 'Sanctions of mass destruction', 78 Foreign Affairs (May/June 1999). 
country, targeted, or smart, sanctions are (theoretically at least) designed to apply pressure on specific individuals or groups without harming the civilian population. The rationale behind smart sanctions is to prevent unintended adverse side-effects to vulnerable populations and overall societies as well as to prevent collateral damage to third-parties. ${ }^{17}$ Targeted sanctions are intended to make up for the ills caused by comprehensive sanctions by being a more effective way to pressure those responsible for objectionable behaviour while preventing collateral damage. ${ }^{18}$ They are tailored to focus "on specific individuals, entities, sectors, and/or regions". ${ }^{19}$ Viewed in this manner, smart sanctions were designed to be more proportionate than comprehensive sanctions regimes.

Despite this shift, targeted sanctions entailing a selective embargo against a State's economic, energy and financial sectors can have unpredictable repercussions on its society, and their impact can be felt beyond that State's borders. Such sanctions are sometimes referred to as sectoral sanctions and are the focus of this present article. In theory, selective embargoes are targeted sanctions, but in practice they can come close to comprehensive sanctions. The reach of these measures is so broad they have the potential to give rise to humanitarian concerns and can cause negative impacts on third parties.

\subsection{Problematic “Targeted" Sectoral Sanctions}

From the practitioner's perspective, an efficient sanction regime is one that hits the target where it will hurt the most. Sanctions practitioner Richard Nephew writes that the "trick of a sanctions campaign [is to subject] a country to such a level of pain that is concedes as swiftly as possible and modifies its behaviour". ${ }^{20}$ This requires knowing the target's political and economic vulnerabilities. More often than not, sanctions are met with resolve from the target, which will find ways to adapt and resist the pain imposed ${ }^{21}$ This can cause the sanctioning entity to intensify the pressure in an effort to crack this resolve.

17 C. Portela, 'Are European Union sanctions “targeted"?', 29:3 Cambridge Review of International Affairs (2016) p. 916, referencing H. Dahlgren, 'Preface', in P. Wallensteen, C. Staibano, and M. Eriksson (eds.), Making targeted sanctions effective. Guidelines for the implementation of UN policy options (Department of Peace and Conflict Research, Uppsala, Sweden, 2003) pp. viii-ix.

18 D. Cortright, G. Lopez, E. S. Rogers, R. R. Newcomb and N. Reid (eds.), Smart sanctions: targeting economic statecraft (Rowman and Littlefield, Lanham, 2002).

19 S. E. Eckert, 'The evolution of effectiveness of UN targeted sanctions', in van den Herik, supra note 4, p. 53 .

$20 \quad$ Nephew, supra note 1, p. 124.

21 On resolve see ibid., chap. 6. 
Although Nephew's conception of sanctions focuses on their coercive purpose - pressuring the State's apparatus to modify behaviour by manipulating its cost-benefit analysis - even if the sanctioner is pursuing a different objective, such as to send a signal, or to constrain, prevent, or punish the target, it is using the imposition of pain to achieve it. From a pragmatic point of view it is unrealistic to expect sectoral sanctions will not have a negative effect on non-targeted individuals and entities. To quote Nephew again: "sanctions are intended to cause pain and change policy" and this will have humanitarian consequences on the "street level". 22 "After all", he writes, "if you intentionally reduce a country's ability to earn foreign currency through exports, then you will almost by definition create at least some pressure on imports, including of food and medicine". ${ }^{23}$ This leads to a series of questions, including: "How do you tailor sanctions to achieve their objective with the minimum necessary pain on the sanctioned target?" 24 This question points to the issue of proportionality; it is phrased in a manner that necessitates balancing the objective of the sender and the required discomfort imposed on the target, including the negative effects on the civilian population. Sanctions can also restrict the activities of economic operators that are not nationals of the targeted State; this issue in particular is a consequence of so-called extraterritorial sanctions.

The Iraq sanctions regime demonstrated the excessive harm, or collateral damage, economic sanctions can inflict upon the civilian population, prompting discussions on these measures' humanitarian impact. ${ }^{25}$ As we saw, by their very nature targeted sanctions should be proportionate; they should constitute an effective means to apply pressure on those responsible for contested behaviour without unduly infringing upon the rights of the civilian population or third parties. Nonetheless the transition from comprehensive to targeted coercive measures has not solved the issue of sanctions' proportionality. ${ }^{26}$ Much less because there is next to no legal framework governing their adoption and sectoral sanctions increasingly resemble comprehensive sanctions.

22 Ibid., p. 12.

23 Ibid.

24 Ibid., emphasis in original.

25 The Iraq government eventually signed a memorandum of understanding with the UN allowing it to sell a minimum quantity of oil to be able to meet the Iraqi people's needs, thus creating the "oil-for-food programme", which was authorised under UN Security Council Resolution 986, adopted 14 April 1995. See Security Council, Letter dated 20 May 1996 from the Secretary-General Addressed to the President of the Security Council (S/1996/356).

26 It is also questionable whether targeted sanctions are more successful in achieving their policy objective, discussed in B.R. Early and M. Schulzke, 'Still Unjust, Just in Different Ways: How Targeted Sanctions Fall Short of Just War Theory's Principles', 21:1 International Studies Review (2018) pp. 10-13. 
Focusing on the humanitarian impact of the EU's "comprehensive restrictive measures" against Iran and Syria, Moret warns of the risks involved in broad targeted sanctions regimes as they come closer to comprehensive measures. ${ }^{27}$ Another article argues that States are using targeted sanctions in a manner that leads to the same unethical outcome as comprehensive sanctions. In the authors' words: "Rather than representing an ethical form of coercion, targeted sanctions simply differ from more comprehensive sanctions in how they violate [Just War Theory] principles." ${ }^{28}$ They find that: "Targeted sanctions [unilaterally adopted by States] continue to indirectly harm innocent people, despite their appearance of precision, which raises concerns about their proportionality, even if they do not specifically target civilians ..." ${ }^{29}$ The social, economic and political effects of sanctions tend to affect the society in general. Finally, according to the Special Rapporteur on the negative impact of unilateral coercive measures on the enjoyment of human rights, Idriss Jazairy, targeted sanctions "entail, to different degrees, adverse consequences on the enjoyment of the human rights of innocent people. There is a very wide range of human rights that might be involved, including political, economic, social and cultural rights." ${ }^{30}$ His reports have focused on autonomous sanctions' impact on "rights to life, health and medical care, an adequate standard of living, food, education, work, housing and development". ${ }^{31}$ Recognising that the EU takes measures to prevent adverse consequences on those targeted, such as by providing humanitarian exceptions, he found there is room for improvement. ${ }^{32}$ He has

27 E. Moret, 'Humanitarian impacts of economic sanctions on Iran and Syria', 24:1 European Security (2015) pp. 120-140. Moret acknowledges that "the term [comprehensive restrictive measures] is confusing in that 'restrictive measures' typically refers to targeted sanctions, though the addition of the term 'comprehensive' suggests they are not".

28 Early and Schulzke, supra note 26, p. 2. In this article the authors apply the principles of "just war theory" to targeted sanctions regimes. Though from a legal perspective these rules are not applicable because the sanctions are adopted in peacetime they can be understood as a useful reference point to discuss the ethical nature of the sanctions.

29 Ibid.

30 HRC, Report of the Special Rapporteur on the negative impact of unilateral coercive measures on the enjoyment of human rights, Idriss Jazairy (UN Doc A/HRC/30/45) para. 18.

$31 \quad$ Ibid.

32 HRC, Report of the Special Rapporteur on the negative impact of unilateral coercive measures on the enjoyment of human rights on his mission to the European Union (UN Doc A/HRC/39/54/Add.1) paras. 39-4O. See also Report of the Special Rapporteur on the negative impact of unilateral coercive measures on the enjoyment of human rights on his mission to the Syrian Arab Republic (UN Doc. A/HRC/39/54/Add.2, advance unedited version) paras. 20-23. See also: Tyller Cullis and Amir Handjani, 'The Anatomy of Humanitarian Trade With Iran', Lawfareblog, 14 May 2019, <https:/www.lawfareblog.com/ anatomy-humanitarian-trade-iran>. 
also argued that sanctions should respect principles of international humanitarian law, even when adopted in peacetime. ${ }^{33}$

The sanctions regime adopted against Iran from 2006 to 2015 provides an illustration of how a series of sectoral sanctions can have the same disproportionate impact of comprehensive sanctions regime. The EU, the United States (US) and other countries adopted unilateral sanctions in 2012 targeting Iran's oil and financial sectors to supplement the existing UNSC sanctions. ${ }^{34}$ The sanctioning authorities believed the extra pressure was required to coerce Iran into complying with its international obligations and into cooperating with the International Atomic Energy Agency (IAEA). ${ }^{35}$ Although the measures were targeted, in that they did not constitute an indiscriminate embargo, "when targeting a vital sector such as oil and petroleum product exports, such 'targeted' measures come to affect, at least indirectly, the whole economy or financial system of a country". ${ }^{36}$ Taken together these sanctions had an overwhelming impact on the target State's economy and overall society, bringing it, according to Joyner, "very close to the situation in which Iraq found itself in the 1990's ... inclusive of the severe humanitarian suffering caused to the civilian populace of the target state". ${ }^{37}$ Because of the costs to civilian well-being, not only is the targeted nature of selective embargoes questionable, ${ }^{38}$ so is their proportionality. Although Iran eventually agreed to the Joint Comprehensive

$33 \mathrm{UNGA}$, Negative impact of unilateral coercive measures on the enjoyment of human rights, Note by the Secretary General (UN Doc A/73/175) para. 21; see also Reisman and Stevick, supra note 4.

34 Legislation enacting unilateral sanctions:H.R.2194, Comprehensive Iran Sanctions, Accountability, and Divestment Act of 2010; Executive Order 13590 of 20 November 2011, available here < https://obamawhitehouse.archives.gov/the-press-office/2011/11/21/executive-order-1359o-iransanctions >; Executive Order 13599 of February 5, 2012, available here: < https://www.treasury.gov/ resource-center/sanctions/Programs/Documents/iran_eo_o2o62012.pdf>; Executive Order 13622 of July 30, 2012, available here < https://www.treasury.gov/resource-center/sanctions/Programs/ Documents/13622.pdf>; Council Decision 2012/35/CFSP of 23 January 2012 amending Decision 2010/413/CFSP concerning restrictive measures against Iran (OJ L 19/22, 24 January 2012); Council Regulation (EU) No 267/2012 of 23 March 2012 concerning restrictive measures against Iran and repealing Regulation (EU) No 961/2010 (OJ L 88/1, 24 March 2012).

35 For a legal discussion on the nature of these measures see P.-E. Dupont, 'Countermeasures and Collective Security: The Case of the EU Sanctions against Iran', 17:3 Journal of Conflict and Security Law (2012) pp. 301-336.

36 HRC, Report of the Special Rapporteur, supra note 30, para. 33.

37 Joyner, supra note 4; see also the study Joyner references: A. Vaez, 'Iran's Nuclear Program and the Sanctions Siege' Arms Control Association, https://www.armscontrol.org/act/2013_05/ Irans_Nuclear_Program_and_the_Sanctions_Siege. See also Moret, supra note 27, according to whom the cumulative effect of the EU's restrictive measures against Iran's financial and energy sectors caused them to become de facto comprehensive sanctions linked to negative humanitarian impacts on the civilian population.

38 Moret, ibid:; see also Portela, supra note 17. 
Plan of Action (JCPOA) with the $\mathrm{P}_{5}+1^{39}$ in 2015, thereby accepting limits to its nuclear development in exchange for sanctions relief, the sanctions contribution to resolving the dispute is debatable. ${ }^{40}$ At the time of writing, the Trump administration has re-imposed stringent sanctions upon Iran, thus reversing President Obama's policy. ${ }^{41}$ Contesting their legality, Iran filed a complaint before the International Court of Justice under the US-Iran 1955 Treaty of Amity, Economic Relations, and Consular Rights in July $2018 .{ }^{42}$

The US sanctions' extraterritorial effects ${ }^{43}$ also raise questions under the proportionality principle. Such measures disproportionately impact third States because they unjustifiably infringe upon their rights to trade and to conduct their foreign policy freely, thereby interfering in their external affairs in a manner that is incompatible with the principle of non-intervention. ${ }^{44}$ To provide one example, under Executive Order 13622 of July 2012, which was re-implemented in $2018,{ }^{45}$ the US unilaterally prohibits the purchase of Iranian oil. ${ }^{46}$ If initially the US provided "Significant Reduction Exceptions" to eight countries, including China and Turkey, in April 2019, the White House announced that the exceptions would not be renewed when they expire in May 2019. ${ }^{47}$ Consequently, actors that are not under US jurisdiction would be subjected to secondary sanctions if they buy oil

39 The $\mathrm{P}_{5}+1$ refers to the five permanent Security Council members, Russia, China, the US, France and the United Kingdom, plus Germany.

40 T. Parsi, Losing an Enemy: Obama, Iran, and the Triumph of Diplomacy (Yale University Press, New Haven, 2017). For an alternative view see Nephew, supra note 1, although Nephew acknowledges Iran demonstrated significant resilience.

41 Executive Order 13846 of August 6, 2018, available here < https://www.treasury.gov/resourcecenter/sanctions/Programs/Documents/o8062018_iran_eo.pdf>; Executive Order 13871 of May 8, 2019, available here < https://www.treasury.gov/resource-center/sanctions/Programs/ Documents/13871.pdf >; Executive Order 13876 of June 24, 2019, available here $<$ https://www. treasury.gov/resource-center/sanctions/Programs/Documents/13876.pdf>.

Pending case before the ICJ: Alleged violations of the 1955 Treaty of Amity, Economic Relations, and Consular Rights (Islamic Republic of Iran $v$. United States of America), <https://www.icjcij.org/en/case/175>, visited 1 November 2019. Hereafter 'Alleged Breaches of the 1955 Treaty'. On extraterritorial sanction see: C. Ryngaert, 'Extraterritorial Export Controls (Secondary Boycotts)', 7 Chinese Journal of International Law (2008) pp. 625-658.

$44 \mathrm{UNGA}$, The Declaration on Principles of International Law concerning Friendly Relations and Co-operation among States (A/RES/2625 (XXV)). P. Terry, 'Letter to the Journal Unilateral Economic Sanctions and Their Extraterritorial Impact: One Foreign Policy For All?, 18:2 Chinese Journal of International Law (2019) pp. 425-235.

45 Executive Order 13846, supra note 41.

46 C. Krauss, 'Trump Hit Iran with Oil Sanctions. So Far, They're Working', The New York Times, 18 September 2019, <https:/www.nytimes.com/2018/og/19/business/energy-environment/iranoil-sanctions.html?action=click\&module=RelatedCoverage\&pgtype=Article\&region=Footer $>$. White House Press Release, 'President Donald J. Trump Is Working to Bring Iran's Oil Exports to Zero', 22 April 2019, <https://www.whitehouse.gov/briefings-statements/ president-donald-j-trump-working-bring-irans-oil-exports-zero/>. 
from Iran..$^{48}$ Another questionable practice is the US' use of its currency to cut actors off from the financial market, ${ }^{49}$ which is possible through "the still-prevalent dollarization of the world economy". ${ }^{50}$ The Trump administration's enthusiastic wielding of this potent tool has aggravated Russia, China and US allies in the EU, to the point where China and Europe are working to weaken the dollar's global dominance. ${ }^{51}$ In spite of their broad reach, these financial sanctions are still dubbed targeted because they are directed towards the financial sector.

As this section has demonstrated, in spite of the shift from comprehensive to targeted sanctions, sectoral sanctions are adopted in such a way that they can have negative humanitarian effects on the civilian population of the targeted State and on third States. To the extent that these measures are adopted in the name of community interests, such as international peace and security, they also involve the interests of the international community. The following section explores the proportionality principle's (limited) application to unilateral sanctions under present international law.

\section{The Proportionality Principle's Current Application to Unilateral Targeted Sanctions under International Law}

As defined above, sanctions are a coercive foreign policy tool. The adoption of unilateral sanctions is considered a State's and international organisation's prerogative to pursue and protect its interests, and there is no general

48 E. Wong and C. Krauss, 'U.S. Moves to Stop All Nations From Buying Iranian Oil, but China Is Defiant', The New York Times, 22 April 2019, <https://www.nytimes.com/2019/04/22/world/ middleeast/us-iran-oil-sanctions-html?module=inline>.

49 J. P. Zoffer, 'The Dollar and the United States' Exorbitant Power to Sanction', 113 AJIL Unbound (2019) pp. 152-156.

50 A. van Aaken, 'Introduction to the Symposium on Unilateral Targeted Sanctions', 113 AJIL Unbound (2019) p. 133 .

$5_{1}$ Zoffer, supra note 49, p. 156. The EU reiterated its opposition to the US' activation of Title III of the Helms-Burton Act: Council of the EU, Declaration by the High Representative on behalf of the EU on the full activation of the Helms-Burton (LIBERTAD) Act by the United States, 2 May 2019, <https:// www.consilium.europa.eu/en/press/press-releases/2019/o5/o2/declaration-by-the-highrepresentative-on-behalf-of-the-eu-on-the-full-activation-of-the-helms-burton-libertad-act-bythe-united-states/> E. Huang, 'A 'growing club' of 'very powerful countries' is steering away from using the dollar', CNBC, 30 October 2019 <https://www.cnbc.com/2019/10/31/de-dollarizationrussia-china-eu-are-motivated-to-shift-from-using-usd.html $>$. There was also a discussion among the EU, China and Russia of creating a "special purpose vehicle" which would permit financial transactions with Iran without using the US dollar, 'Remarks by High Representative/ Vice-President Federica Mogherini following a Ministerial Meeting of E3/EU +2 and Iran', 24 September 2018, <https://eeas.europa.eu/headquarters/headquarters-homepage/51040/ remarks-hrvp-mogherini-following-ministerial-meeting-ezeu-2-and-iran_en>. 
prohibition to adopt unilateral sanctions under customary international law. The consequence is that in spite of abundant (Western) State practice, unilateral sanctions are "one of the least developed areas of international law".52 Although some restrictions apply, for the most part there are many legal gaps, or grey areas, surrounding unilateral sanctions.

One notable exception is the countermeasure regime that is found in the Articles on Responsibility of States for Internationally Wrongful Acts (ARSIWA) that were drafted by the International Law Commission (ILC) and that are generally understood as a codification of customary international law. Countermeasures are a circumstance precluding wrongfulness; they are an internationally wrongful act adopted by a State or by an international organisation ${ }^{53}$ in response to an injury it suffered from a previous wrongful act committed by the target State. As defined under ARsiWA Article 49(1), the purpose of these measures is to pressure ("induce") the target into ceasing its initial wrongful behaviour and to offer, where appropriate, guarantees of non-repetition and reparation; they are coercive acts. ${ }^{54}$ Countermeasures adopted by a directly injured State or international organisation - as opposed to third-party, or collective, countermeasures adopted by non-directly injured States or international organisation in response to violations of community obligations are the only legal regime with a defined proportionality threshold, which the ILC drew from international jurisprudence. ${ }^{55}$ It should be noted that, in addition to the condition that countermeasures be proportionate to the initial wrong under Article 51 ("commensurate with the injury suffered"), further limits to countermeasures are found in other ARsiwA provisions. Under Article 49(1) countermeasures may only be taken against the responsible State (and

$5^{2}$ N. D. White and A. Abbas, 'Countermeasures and Sanctions', in M. D. Evans (ed), International Law (Oxford University Press, Oxford, 2014) p. 537; reiterated in D. Hovell, 'Unfinished Business of International Law: The Questionable Legality of Autonomous Sanctions', 113 AJIL Unbound (2019) pp. 140-145, who concluded at p. 144: "Powerful states continue to deploy autonomous sanctions. The problem is that a great deal of this practice remains unregulated or based on questionable legality."

53 ILC, Draft articles on the responsibility of international organizations in Yearbook of the ILC, vol. II(2), 2011, (UN Doc A/CN.4/SER.A/2011/Add.1), Part 2, Article 22. On international organizations' capacity to adopt countermeasures see: C. Beaucillon, Les mesures restrictives de l'Union européenne (Bruylant, Bruxelles, 2014) pp. 329-334 and pp. 424-430, and F. Dopagne, Les contre-mesures des organizations internationales (Anthemis, Louvain-la-Neuve, 2010).

54 But see Cannizzaro, supra note 11, for a more nuanced view.

55 Notably: Gabcikovo-Nagymaros Project (Hungary/Slovakia), 25 September 1997, Judgment, ICJ, < https://www.icj-cij.org/en/case/92/judgments >, para. 85 . 
therefore must not affect the rights of third parties) ${ }^{56}$ Consequently, any limitations on the rights and interests on non-responsible actors would not be justified under the countermeasure framework. Furthermore, though the scope of the provision is unclear, under Article 5o(1)(c) (collective) countermeasures are barred from negatively affecting "obligations for the fundamental protection of human rights".

There is no uniform (legal) limit to the amount of pain, or coercion, that can be imposed through sanctions as long as the measure respects a primary obligation. The main principle that regulates such coercive acts is the principle of non-intervention. An act of coercion would violate this norm if it constitutes an irresistible pressure that forces the will of another State in an area of its domaine réservé. ${ }^{57}$ In general, however, the principle is more readily applicable to acts involving the use of force than to non-forcible coercive measures. Aside from the prohibition of intervention, States have the freedom to adopt sanctions provided these respect their obligations under international law. ${ }^{58}$ The primary restriction in adopting sanctions is that these measures must respect the obligations the sending entity owes the target under customary international law, bilateral treaties or multilateral treaties to which they are both party. If sanctions respect this condition they amount to acts of retorsion, traditionally defined as lawful but unfriendly acts. If not, they would constitute an internationally wrongful act that could potentially be justified as a countermeasure.

The present section provides a brief overview of the proportionality principle's application in the context of retorsions, countermeasures and collective countermeasures.

56 ARsiwa commentaries, supra note 57, p. 130, paras. 2 and 4. See also: Corn Products International v Mexico, Decision on Responsibility, ICSID Case No ARB(AF)/o4/o1 (15 January 2008) paras. 180-192.

57 Drawn from ILC, Draft Articles on Responsibility of States for Internationally Wrongful Acts with Commentaries, in Yearbook of the ILC II(2), 2001, (UN Doc A/CN.4/SER.A/2001/Add.1), Part 2, hereafter 'ARSIWA commentaries', Article 18 on 'Coercion of another state', pp. 69-70. See also: Military and Paramilitary Activities in and against Nicaragua (Nicaragua v. United States of America), 27 June 1986, ICJ, Judgment, < https://www.icj-cij.org/files/caserelated/70/o70-19860627-JUD-o1-oo-EN.pdf>, para. 205: "A prohibited intervention must accordingly be one bearing on matters in which each State is permitted, by the principle of State sovereignty, to decide freely. ... Intervention is wrongful when it uses methods of coercion in regard to such choices, which must remain free ones." In spite of this, coercion remains notoriously undefined international law. See further M. Helal, 'On Coercion in International Law', 52:1 New York University Journal of International Law and Politics (JILP) (2019) pp. 1-122.

$5^{8}$ Sanctions therefore fall between the prohibition of intervention and the 'Lotus Principle', The Case of the S.S Lotus (France v. Turkey), Judgment, PCIJ, 7 September 1927, p. 18. 


\subsection{Retorsions}

The common definition of a retorsion is that of a lawful but unfriendly act. As acts of retorsion are necessarily lawful, States enjoy a wide margin of discretion. According to Giegerich, the proportionality principle would not impose any legal limits to retorsions; any restriction would be of an ethical or political nature. ${ }^{59}$ Acts of retorsion constitute sanctions that, for instance, would violate a treaty between the sanctioner and the sanctioned but that fall within the purview of permitted derogations. The General Agreement on Trade and Tariffs (GATT) allows signatories to take measures that transgress their obligations under the treaty in certain exceptional circumstances found in Article XX and Article XXI. Similar exceptions are also found within bilateral agreements, for instance the International Court of Justice will have to address the invocation of a security exception in the merits phase of Alleged Breaches of the 1955 Treaty between Iran and the US. Whether unilateral sanctions fall within the scope of security exceptions that are found in bilateral treaties and in multilateral treaties is a recurring topic.

GATT Article XXI(b) in particular has been the subject of much discussion. ${ }^{60}$ It reads:

Nothing in this Agreement shall be construed ...

(b) to prevent any contracting party from taking any action which it considers necessary for the protection of its essential security interests

(i) relating to fissionable materials or the materials from which they are derived;

(ii) relating to the traffic in arms, ammunition and implements of war and to such traffic in other goods and materials as is carried on directly or indirectly for the purpose of supplying a military establishment;

(iii) taken in time of war or other emergency in international relations.

The provision has frequently been described as self-judging. Nonetheless according to a World Trade Organization (wTO) Panel's landmark reading in Russia - Measures Concerning Traffic in Transit, the clause is not entirely immune from scrutiny: "for action to fall within the scope of Article XXI(b), it

59 T. Giegerich, 'Retorsion' in Wolfrum, supra note 6, vol. viII, para. 14; see also O. Schachter, International Law in Theory and Practice (Martinus Nijhoff, The Hague, 1991) p. 199, quoted in Dupont, supra note 35, p. 315 .

6o R.J. Neuwirth and A. Svetlicinii, 'The Economic Sanctions over the Ukraine Conflict and the WTO: 'Catch-XXI' and the Revival of the Debate on Security Exceptions', 49:5 Journal of World Trade (2015) pp. 891-914. 
must objectively be found to meet the requirements in one of the enumerated subparagraphs of that provision".61 Specifically, with regard to GATT Article xxI(b)(iii) the Panel considered that:

as the existence of an emergency in international relations is an objective state of affairs, the determination of whether the action was 'taken in time of' an 'emergency in international relations' under subparagraph (iii) of Article $\mathrm{XXI}(\mathrm{b})$ is that of an objective fact, subject to objective determination. ${ }^{62}$

The phrase "which it considers" is indicative of the provisions' subjective component; once the factual context can be objectively determined, the State decides itself which measures are necessary. The Panel is not competent to assess, therefore, whether there would be an alternative that would not violate or that would be less violative of the GatT provisions. ${ }^{63}$ The Panel also found it is competent to determine whether Article XXI(b) is invoked in good faith, i.e. that the provision is not raised abusively in order to circumvent WTO obligations. ${ }^{64}$ In other words, under GatT Article XXI the Panel's jurisdiction is limited to verifying a causal connection between the measure adopted and whether the condition outlined in the sub-headings are met.

The Grand Chamber of the Court of Justice of the EU addressed the scope of another security exception in the Rosneft case. Rosneft - a Russian-owned company that was listed in the EU's sanctions regime adopted in response to Russia's actions in Ukraine in 2014 - challenged the EU restrictive measures before the High Court of Justice (England \& Wales), which referred the matter to the Court of Justice. Amongst others claims, Rosneft argued that the measures violated the EU-Russia Partnership and Cooperation Agreement. The Grand Chamber, however, ruled that the restrictive measures were consistent with Article 99(1) of the Agreement, which allows for the adoption of measures in response to security issues. ${ }^{65}$ The judges recalled: "the Council has a broad discretion in areas which involve the making by that institution of political,

61 Russia - Measures Concerning Traffic in Transit (DS512), WTO, Panel Report of 29 April 2019, < https://www.wto.org/english/tratop_e/dispu_e/cases_e/ds512_e.htm> p. 5o, para. 7.101.

$62 \quad$ Ibid., 42, para. 7.77; see also paras. 7.70-7.76.

63 Ibid., para. 7.108.

64 Ibid., paras. 7.132-7.133.

65 Judgment of the Court, Grand Chamber, 28 March 2017, Case C-72/15, <http://curia.europa. eu/juris/document/document.jsf?text=\&docid $=189262 \&$ pageIndex $=0 \&$ doclang $=$ en\&mode $=$ lst \&dir $=\&$ occ $=$ first\&part $=1 \&$ cid $=595582>$. 
economic and social choices". ${ }^{66}$ They found that the adoption of restrictive measures "was necessary for the protection of essential European Union security interests and for the maintenance of peace and international security".67 In light of the circumstances and the interests at stake, the judges let the deciding body, the Council, determine the type of necessary measures.

Overall, in the two cases reviewed, the test applied to security exceptions is if the limitations that arise from the sanctions are justified by the circumstances and by the public interests the sanctioning party is acting to defend. In neither the што Panel Report nor the Rosneft judgment was a proportionality assessment strictu sensu - that is a balancing act between the sanctioner's interests and the restrictions imposed upon those affected - carried out. The bench's job, therefore, is to guarantee that the exception has been raised in good faith.

On the other hand, the ICJ s Order of October 2018 on Iran's request for provisional measures in Alleged Breaches of the 1955 Treaty case could be indicative of the fact that humanitarian interests and circumstances where harm could be caused to human life, such as civil aviation safety, should not be affected by measures taken under the security exceptions. ${ }^{68}$ Furthermore, in that case, Judge ad hoc Momtaz raised the issue of the US sanctions' extraterritorial effect. His declaration states that the US' extraterritorial sanctions are prima facie violations of GATT, taking into account the fact that Iran is not a WTO Member, the sanctions' extraterritorial nature violates the rights of third parties, such as the EU.69

Taking stock of the ICJ's order as well as the potentially harmful consequences of sanctions as discussed in section 2, it is suggested here that the

66 Ibid., para. 113 .

67 Ibid., para. 116. This finding was later upheld by the General Court: Judgment of the General Court of 13 September 2018, <http://curia.europa.eu/juris/document/document.jsf?text=\&d ocid=205646\&pageIndex=o\&doclang=EN\&mode=lst\&dir=\&occ=first\&part=1\&cid=741105>, paras. $178-179$.

68 Alleged Breaches of the 1955 Treaty, supra note 42, Request for the Indication of Provisional Measures, 3 October 2018, < https://www.icj-cij.org/en/case/175/orders >, paras. 69-70, 89, 91-92, 98 and para. 102, 1 and 2. See also: Ibid., Separate Opinion of Judge Cançado Trindade, <https://www.icj-cij.org/files/case-related/175/175-20181003-ORD-o1-o1-EN. pdf $>$. Since the Court's order, Human Rights Watch published a report warning on the consequences these restrictions could have on the Iranian people's access to medicine. HRW, “Maximum Pressure” US Economic Sanctions Harm Iranians' Right to Health', 29 October 2019, <https://www.hrw.org/report/2019/10/29/maximum-pressure/ us-economic-sanctions-harm-iranians-right-health>.

69 Request for the Indication of Provisional Measures, supra note 68, Declaration of Judge ad hoc Momtaz, <https://www.icj-cij.org/files/case-related/175/175-20181003-ORD-o1-o2-FR.pdf>, paras. $22-23$. 
"freedom" to adopt retorsions should be constrained. Such a suggestion may appear illogical as retorsions are, by definition, lawful, and hence unregulated acts that fall outside the scope of international law. Yet, to quote White and Abbas, "it seems odd that acts of retorsion which could be more damaging than countermeasures may be acceptable but this seems to reflect the under-developed state of international law in this area". ${ }^{70}$ In their view, and contrary to Giegerich's claim, retorsions "are still governed by the limitations of necessity and proportionality". ${ }^{71}$ The issue lies in not only how these limitations would apply but also in re-defining acts of retorsion. If we are willing to re-define acts of retorsion as a State's exercise of a right - which, as opposed to a freedom, implies duties and obligations ${ }^{72}$ - then the abuse of rights doctrine could be a helpful starting point in regulating these measures. ${ }^{73}$ According to Kiss' definition, this concept "refers to a State exercising a right either in a way which impedes the enjoyment by other States of their own rights or for an end different from that for which the right was created, to the injury of another State." ${ }^{74}$

He goes on to explain that an abuse of rights may occur in three distinct legal situations, and the third is most relevant to the discussion on retorsions: "the arbitrary exercise of its rights by a State, causing injury to other States but without clearly violating their rights, can also amount to an abuse of right". ${ }^{75}$ Here it is not a matter of the harm caused to legal rights, but of the pain or disutility caused to the object of the act of retorsion. Following this logic, a selective embargo that may initially be considered an act of retorsion but that provokes excessive damage to the embargoed State could amount to an abuse of rights because of its disproportionate effects. Schachter suggests that retorsions that pursue an illegitimate aim, such as coercing a State to give up a sovereign right, would constitute an abuse of rights. ${ }^{76}$ Against this backdrop, the proportionality assessment involves taking into account the goal pursued by the sender (hence the functional approach to proportionality discussed above), the limits imposed on the target and the impact on those that are not targeted. The test should be applied before deciding whether a sanction is an act of retorsion. Consequently, States adopting unilateral sanctions should respect the

$70 \quad$ White and Abbas, supra note 52, p. 538.

71 Ibid. See also: P. Daillier, M. Forteau, A. Pellet, Droit International Public, $8^{\mathrm{e}}$ ed. (LGDJ, Paris, 2009) pp. 1056-1057, para. 573 .

72 J. Crawford, State Responsibility: the General Part (Cambridge University Press, Cambridge, 2013) p. 677 .

73 As argued by Dallier et al, supra note 71 .

74 A. Kiss, 'Abuse of Rights' in Wolfrum, supra note 6, vol. I, p. 20, para. 1.

75 Ibid., para. 6. (emphasis added).

76 Schachter, supra note 59 . 
proportionality principle, lest a disproportionate sanction would constitute an internationally wrongful act and engage their international responsibility, which could logically not be justified as a countermeasure.

\subsection{Countermeasures}

Whereas (almost) no one would question the adoption of retorsions, ostensibly because they are lawful, countermeasures were highly controversial during the drafting of ARSIWA. ${ }^{77}$ Because of the issues raised, the conditions imposed upon countermeasures aim to keep these otherwise crude tools as "polite" as possible. ${ }^{78}$ This is the case of the proportionality principle, which would prevent abuse, overreaction ${ }^{79}$ and escalation, ${ }^{80}$ bar extreme economic coercion ${ }^{81}$ and avoid sanctions from being a form of punishment. ${ }^{82} \mathrm{~A}$ disproportionate countermeasure would give the targeted State the opportunity to invoke the responsibility of the injured State adopting the measure. Following the "eye for an eye" adage, countermeasures are expected to create a balance between the injured State whose rights have been violated and the responsible State. This tit-for-tat logic is reflected under Article 51, according to which countermeasures are required to be "commensurate with the injury suffered, taking into account the gravity of the internationally wrongful act and the rights in question". ${ }^{83}$ The beginning of the provision suggests that the proportionality

77 D. Bederman, 'Counterintuiting countermeasures', 96:4 American Journal of International Law (2002) p. 817 .

78 Ibid., p. 83 .

79 Cannizzaro, supra note 7, p. 890.

80 T. Franck, 'On Proportionality of Countermeasures in International Law', 102:4 American Journal of International Law (2008) p. 715; R. O'Keefe, 'Proportionality', in J. Crawford, A. Pellet and S. Olleson (eds), The Law of International Responsibility (Oxford University Press, Oxford, 2010) p. 116o.

81 J. Crawford, The International Law Commission's Articles on State Responsibility, Introduction, Text and Commentaries (Cambridge University Press, Cambridge, 2002) pp. 50-51; O'Connell, supra note $25, \mathrm{p} .77$.

82 ARSIWA commentaries, supra note 57, commentary to Article 51, p. 135, para. 7. Though if sanctions are de facto a form of punishment it is questionable to what extent the proportionality principle could alleviate this.

83 Initially, the Articles adopted on First Reading, required that "[c]ountermeasures taken by an injured State shall not be out of proportion to the degree of gravity of the internationally wrongful act and the effects thereof on the injured State". (Article 49). This final version of Article $5_{1}$ emerged from a feedback loop between the Commission and the ICJ judges. The wording of Article 51 is an exact replica of the Gabcikovo-Nagymaros Project, supra note 55, para. 89, which was issued in 1997. In that judgment, the Court references the Draft Articles on State Responsibility adopted in 1996, wherein it is required that a legitimate countermeasure be "commensurate with the injury suffered as result of the offence in question", Commentary to Draft Article 30, para. 5 . 
test is quantitative; "the scope and effect" of the countermeasure must not surpass the initial wrong. ${ }^{84}$ Nonetheless, the commentaries to the Draft Articles specify that the qualitative factors should be taken into account, which the Article includes under the phrase "the rights in question". These would contain "not only the effect of a wrongful act on the injured State but also on the rights of the responsible State. Furthermore, the position of other States which may be affected may also be taken into consideration." 85

The provision is primarily drawn from the ICJ s Gabcikovo-Nagymaros judgment. ${ }^{86}$ However, the case itself provides no guidance on how the test should be carried out. ${ }^{87}$ The proportionality of countermeasures was slightly more developed in the Air Service Agreement Arbitration between France and the United States, which inspired the second part of Article 51. The Tribunal's approach was "to take into account not only the injuries suffered by the companies concerned but also the importance of the questions of principle arising from the alleged breach". ${ }^{88}$ By including the matter of principle, the proportionality of the countermeasure involved an assessment of the interest at stake. In light of the importance of the issue, the Tribunal found that "the measures taken by the United States do not appear to be clearly disproportionate when compared to those taken by France". 89 Washington's response to Paris' initial wrongful act sent a signal to third States with which the US had air transport agreements.

Article 51, which seeks a balance between the breach and the response, does not take into account the objective of countermeasures in determining their proportionality, ${ }^{90}$ a shortcoming according to multiple scholars. ${ }^{91}$ By requiring the injury caused by the countermeasure to be equivalent to the injury resulting from the initial wrongful act, some commentators find that countermeasures

84 R. Kolb, The international law of state responsibility: an introduction (Edward Elgar Publishing, Northhampton MA, 2017) p. 180.

85 ARSIWA commentaries, supra note 57, commentary to Article 51, p. 135, para. 6.

86 Supra notes 55 and 83 .

87 Franck, supra note 8o, p. 739, according to whom the bench seemed to assume that any reasonable person would have reached the same conclusion. But Cannizzaro, supra note 11, p. 898 , finds that the Court's assessment was based on the proper function of the measure adopted by Slovakia.

88 Case concerning the Air Service Agreement of 27 March 1946 between the United States of America and France, UnRIAA, vol. XVIII (Sales No. E/F.8o.V.7) p. 443, para. 83.

89 Ibid.

$90 \quad$ However see Ibid., p. 135, para. 7 .

91 Cannizzaro, supra note 11; A. Cassese, International Law (Oxford University Press, Oxford, 2005) p. 306, quoted in White and Abbas, supra note 52, pp. 539-540, who agree; L.-A. Sicilianos, 'La Codification des Contre-Mesures par la Commission du Droit International', Revue Belge de Droit International (2005) pp. 482-483. 
take on the form of punishment ${ }^{92}$ or an act of "private revenge". ${ }^{93}$ Cannizzaro writes that Article 51 is inconsistent with the premise that countermeasures are coercive by nature; its conditions may seriously thwart the pursuit of compliance. ${ }^{94}$ In the context of Article 51, the proportionality principle is consistent with countermeasures' aim to re-create a balance between the rights of the injured State and the responsible State. Appraising proportionality on the basis of their coercive function, as defined under Article 49, would give States an unconditional power of enforcement, as the sanctioner may apply maximum pressure in pursuit of compliance. ${ }^{95}$ In addition, the issue of sanctions being necessary to achieve their aim, thus of their effectiveness, further complicates the discussion as these policy tools have a low track record of successfully inducing compliance. ${ }^{96}$ How this impacts the proportionality assessment remains an open question, but we should be open to questioning the appropriateness of measures that are too frequently ineffective.

\subsection{Collective Countermeasures}

Whether an unlawful sanction adopted by a non-directly, or indirectly, ${ }^{97}$ injured State or organisation in defence of a community or collective obligation, an obligation erga omnes (partes), can be justified as a so-called "thirdparty countermeasure", or collective countermeasure, has been debated since at least the drafting of the Articles on State Responsibility. The ILC left the matter of their legality open to the further development of international law and settled for a savings clause, Article $54 .{ }^{98}$ Third States would be entitled to adopt collective countermeasures against another State that, for instance, committed grave violations against a civilian population (usually its own) or against another State. The ILC initially suggested that collective countermeasures

92 E. Katselli Proukaki, The problem of enforcement in international law: countermeasures, the non-injured state and the idea of international community (Routledge, New York, 20o9) pp. 277-278; White and Abbas, supra note 52, p. 539.

93 Cannizzaro, supra note 11.

94 Ibid., p. 894.

95 Ibid., p. 9o8. On maximum pressure recall supra notes 20-21 and accompanying text.

96 It is notably because sanctions are ineffective at coercing a change in behaviour that attention is drawn to their other functions, L. Jones and C. Portela, 'Evaluating the Success of International Sanctions: A New Research Agenda', No. 125 Afers Internacionals (2020) pp. 39-6o.

97 Sicilianos, supra note 91, p. 473 .

98 For a discussion on third-party countermeasures see C. Tams, Enforcing Obligations Erga Omnes in International Law (Cambridge University Press, Cambridge, 2005), Katselli, supra note 92, M. Dawidowicz, Third-Party Countermeasures in International Law (Cambridge University Press, Cambridge/New York, 2017). 
should be subjected to the same conditions as bilateral countermeasures; ${ }^{99}$ the difficulty is translating this in practice. One such difficulty is that of applying the proportionality test under Article 51. As Dawidowicz writes, in the context of collective countermeasures, the role of reciprocity in measuring proportionality disappears altogether and "the requirement of equivalence between breach and response provides a very crude yardstick". ${ }^{100}$ In spite of State practice in response to violations of human rights abroad or the measures adopted against Russia for the violation of Ukraine's territorial and sovereign integrity, international law in this area remains undeveloped, and it cannot be ascertained that collective countermeasures are accepted under customary international law. ${ }^{101}$

Collective countermeasures can pose the issue of multiple States reacting to enforce a norm that is of importance to a group of States or the international community as a whole. Special Rapporteur Crawford therefore proposed that the cumulative effect of collective countermeasures should not violate the principle of proportionality. ${ }^{102}$ Under such circumstances it is expected that the senders would collaborate to ensure their measures are proportionate when combined. However, in instances where States have acted in response to situations of international concern, the sanctioners appear to have cooperated to make sure pressure is applied in the most efficient manner. ${ }^{103}$ Without discussing the sanctions' legal nature, ${ }^{104}$ as we saw in the case of the sanctions regime adopted against Iran before the adoption of the JCPOA the EU, the US and their allies seemed to have coordinated their efforts to apply pressure in the most efficient way possible. Currently, the Trump administration's desire to re-impose maximum pressure on Iran has pushed the US to adopt extraterritorial

99 State Responsibility, Draft Articles Provisionally Adopted by the Drafting Committee on Second Reading (UN Doc. A/CN.4/L.6oo) 21 August 200o, Draft Article 54(3) [2000]: "Where more than one State takes countermeasures, the States concerned shall cooperate in order to ensure that the conditions laid down by this Chapter for the taking of countermeasures are fulfilled".

100 Dawidowicz, supra note 98, p. 347.

101 A. Hofer, 'The Beliefs and Practice of Enforcing Collective Obligations through Unilateral Sanctions' thesis submitted and defended at Faculty of Law and Criminology, Ghent University, Ghent, Belgium, 2019, pp. 22-40. For a contra position see Dawidowicz, supra note 98.

102 ILC, Third report on State responsibility, by Mr. James Crawford, Special Rapporteur (2000) UN Doc A/CN.4/507 and Add. 1-4*, p. 105, para. 401: "[A]ll the countermeasures taken in relation to a particular breach should be considered in determining whether the response is, overall, proportionate".

103 Moret, supra note 27; Early and Schulzke, supra note 28.

104 Dupont, supra note 35 . 
sanctions; their chilling effect is such that non-US economic and financial actors prefer to not do business in Iran rather than risk hefty US fines.

Finally, in the discussion on "whose interests count?", the interests of international community or of the collective to which the obligation breached is owed should be included in the equation. The case between Iran and the US, for instance, is a matter of international security and hence a concern to the international community as a whole. ${ }^{105}$ Though the US may claim it is acting in its own interests and those of the international community, what is the appropriateness of these sanctions and are they genuinely necessary? Far from strengthening the multilateral system, President Trump's policy is undermining it. ${ }^{106}$ The precedent is an invitation to re-assess the use of sanctions and to explore venues for further regulation, regardless of the sanctions' legal qualification.

\section{$4 \quad$ Moving Forward: Whose Interests Should Count?}

If targeted sanctions are supposed to be proportionate - in that they should not have adverse negative effects on segments of the civilian population nor cause collateral damage to third-parties - it is apparent that there is no straightforward answer to what a proportionate sanction is. That being said, if we acknowledge sanctions constitute the infliction of harm, or "strategically applied force", ${ }^{107}$ regardless of the objective pursued, then there should be rules guiding their adoption. A starting point would be a uniform approach to the proportionality of unilateral sanctions, even to acts of retorsion. In making this assessment, the interests the sanctioner is seeking to defend should be weighed against the interests of the target and those that are not targeted but still affected. In addition, when sanctions are adopted in the name of the community of collective interests, their impact on the multilateral order should be considered. Consequently, the interests that should count extend beyond the sanctioner and the sanctioned, but include those that would be affected.

The imposition of pain on the target, as well as the "collateral damage" caused by sanctions, should be proportionate in relation to the sender's exercise of its right to adopt sanctions and also in relation to the legitimate goal pursued. One common thread that is found throughout the different legal regimes analysed

105 Separate Opinion of Judge Cançado Trindade, supra note 68, paras. 78 - 92.

106 M.J. Menkes, "The Legality of US Investment Sanctions against Iran before the ICJ: A Watershed Moment for the Essential Security and Necessity Exceptions', 56 Canadian Yearbook of International Law (2019) pp. ${ }^{228-364 .}$

107

Supra note 1 and accompanying text. 
above is the type of interests the sender is seeking to uphold, whether it is acting in its own interests, in the interests of a group of States or in the interests of the international community. The more vital the interest, the more restrictions imposed through sanctions would be justified. The risk with this approach, however, is that the imposed pressure may become superfluous; pain is imposed in the name of principles and without their being any clear objective. Rather than a deferential attitude towards the adoption of unilateral coercive measures, a more thorough balance of the interests at stake is required; one that takes into account the interests of the target and all other parties that may be affected, particularly when the costs imposed hurt the civilian population. An assessment of sanctions' proportionality requires a narrative of who would be affected. It also requires taking due consideration of the goal that is pursued by the sanctioner and the appropriateness of the sanction in achieving this goal; this would apply further limits to States' right to adopt the policy tools and prevent abusive practices. Finally, the proportionality of sanctions should include the condition of necessity. The circumstances that give rise to their adoption need to be factually and objectively ascertained. This factual assessment was carried out in the WTO Panel's reading of GATT Article XXI(b) and in the Grand Chamber's Rosneft judgment. Under ILC Draft Article 49(1), the necessity of the measure, i.e. a previous wrongful act, is a condition for the adoption of countermeasures. However, State practice is demonstrative of the fact that whether sanctions are necessary should be subjected to greater scrutiny. It also should be linked to whether these tools enable the sender to achieve its goal and whether a less intrusive measure is available. Though proportionality and effectiveness are separated in sanctions' legal doctrine, in reality this is an artificial distinction. States sometimes forego considerations of proportionality because they believe it will enhance effectiveness. If there is no limit setting the "reasonable" amount of pain that can be imposed through a sanction, this can lead to harmful practices.

Ultimately, as made clear through this article, the proportionality of sanctions poses questions not only regarding whose interests count, but also on their appropriateness and their necessity within inter-State relations, quagmires that could not be satisfactorily addressed here and that cannot be solved by the proportionality principle. In discussions on the regulations of unilateral sanctions, what is needed is a more informed debate on how sanctions work, what their purposes are and the effect they have not only on the targeted State but also the global environment. An interdisciplinary study that draws from international relations scholarship is required. But, as anyone familiar with the literature already knows, in spite of centuries of sanctions' practice there is no unanimity on whether sanctions work and on how they work. Much like the proportionality principle, sanctions are an inexact science. 